\title{
Accumulation of mesozooplankton in a wake area as a causative mechanism of the "island-mass effect"
}

\author{
S. Hernández-León \\ Facultad de Ciencias del Mar, Apartado 550, Las Palmas de Gran Canaria, Canary Islands \\ Date of final manuscript acceptance: December 14, 1990. Communicated by J.M. Pérès, Marseille
}

\begin{abstract}
Mesozooplankton biomass (as displacement volume and protein content) and electron-transport system (ETS) activity have been studied in the coastal waters around the Canary Islands. Increases in biomass and ETS activity, on a unit volume basis, were observed in the wakes of the islands. The biomass values obtained in the leeward area for Gran Canaria Island were up to ten times higher than those observed for typical oceanic waters around this archipelago. Sampling was performed in May 1986 at the end of the characteristic vertical mixing period in these waters. Relatively strong winds were recorded prior to sampling. Specific ETS activity was higher at the windward stations on the island shelf. This correlates with the observation in a recent study of increased primary production on the shelf area, where turbulence produced by the northerly trade winds has a marked effect. The persistence of this turbulence during a prolonged wind-pulse results in an accumulation of organisms in the wake of the islands due to current dynamics. This process is proposed as being an important causative mechanism of the island-mass effect. Different biomass values were recorded between circular and oblong islands. The latter are oriented towards the current and the northerly trade winds, and display significantly lower biomass values than the former.
\end{abstract}

\section{Introduction}

The increase in planktonic biomass due to perturbation produced by subtropical islands in the general oceanic circulation is an enrichment phenomenon which could be important to the highest trophic levels. The stock of coastal planktotrophic fishes (mackerel, sardine, etc.) is an important factor affecting the presence of tuna near islands (Blackburn 1965, Sund et al. 1981). The environmental characteristics of Canary Island waters have been discussed in previous works (De León and Braun 1973, Braun 1980, 1981, Hernández-León et al. 1984, Fernández De Puelles 1986, Hernández-León 1987, 1988a). Oligotrophy and the presence of a late winter bloom are general characteristics of the waters around the Canaries.
In recent years, we have observed that physical factors such as wind-pulses have an important effect on the coastal waters of the Canary Islands. Increases in mesozooplankton biomass following wind-pulses were recorded by Hernández-Léon (1988 a); e.g. off the leeward side of the south coast of Gran Canaria, a mesozooplankton maximum was observed coinciding with the maximum strength of the northerly trade winds in summer. The values recorded were several times higher than those reported by different authors for typical oceanic waters around these islands.

In recent works (Hernández-León 1986, 1987, 1988 a, b, Hernảndez-León and Miranda-Rodal 1987), mesozooplankton gradients have been reported for wind-shear areas of the island when, after a wind-calm period, a northerly trade-wind pulse is produced. The causative mechanisms were discussed in these papers, but possible differences between windward and leeward areas were not investigated.

During May 1986, we had the opportunity of studying the mesozooplankton biomass and ETS activity and of sampling coastal waters around the entire archipelago, with the aim of investigating increases in biomass observed around the island of Gran Canaria at the end of the period characterized by vertical water-mixing. The sampling area was larger than that in earlier studies (Hernández-León 1986, 1987, $1988 \mathrm{a}$, b), which had focused on the leeward area of the island. The possible effect of island shape was also investigated by sampling a circular island (Gran Canaria) and two oblong islands (Lanzarote and Fuerteventura, considered as one unit); the latter two islands are oriented towards the current and the northerly trade winds (Molina and Laatzen 1986). Data obtained around four further islands were used to compare and elucidate the general biological processes in the archipelago as a whole.

\section{Materials and methods}

Plankton was collected during the "Ecos 8605 " cruise with R. V. "Taliarte", 13 to 31 May 1986. Data on wind direction and speed 


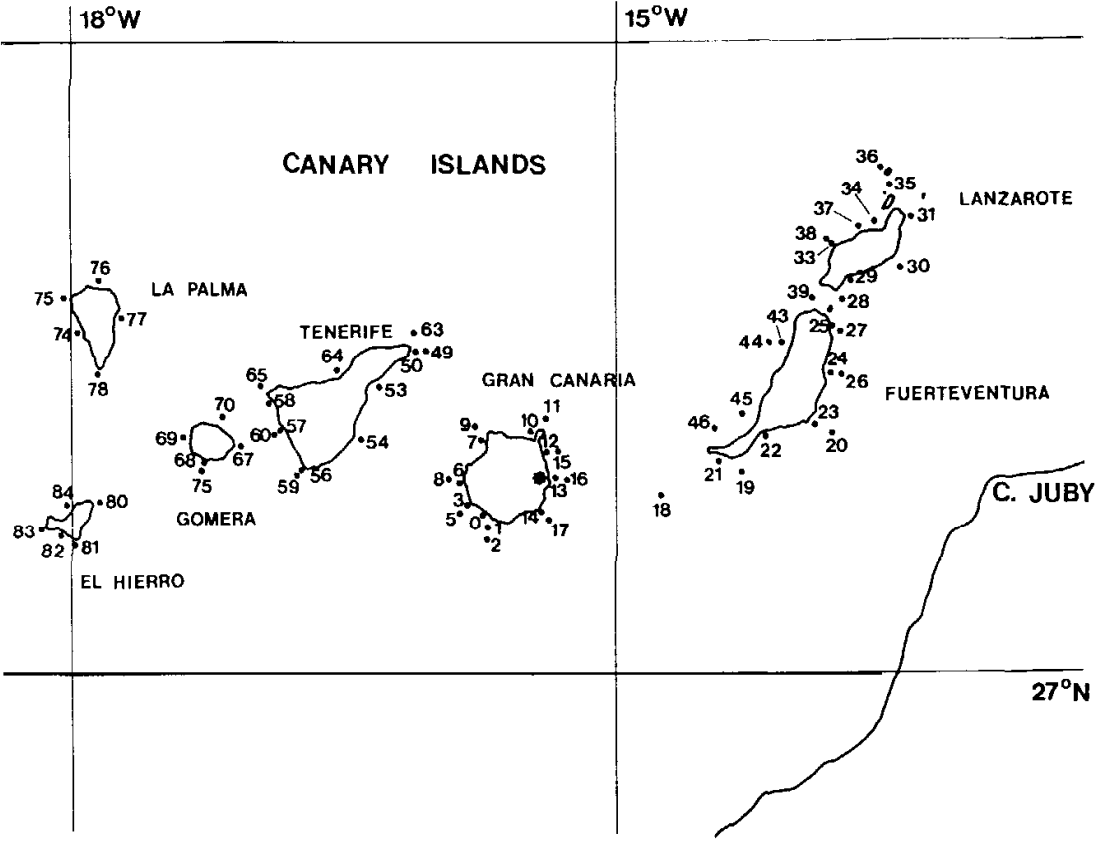

Fig. 1. Location of sampling stations around Canary Islands; asterisk on Gran Canaria island shows position where wind data were recorded were provided by the "Instituto Nacional de Meteorologia" at Gran Canaria airport; this station was chosen for its advantageous position for recording the northerly trade winds.

Mesozooplankton was collected at each station from 0 to $200 \mathrm{~m}$ or 0 to $5-10 \mathrm{~m}$ from the bottom, depending on water-column depth, by means of vertical hauls using a WP-2 triple net, which is a version of the standard WP-2 (UNESCO 1968). Three samples were taken at each station. One sample was used for determining biomass as displacement volume and as protein content and also for measuring ETS activity. This sample was immediately frozen in liquid nitrogen $\left(-196^{\circ} \mathrm{C}\right)$ and later analyzed in the laboratory. Proteins were assayed following the method proposed by Lowry et al. (1951), using bovine serum albumine (BSA) as standard. In order to compensate for any nocturnal/diurnal differences, night: day ratios of 1.37 for displacement volume and 1.85 for the protein content were calculated. ETS activity was determined in accordance with Packard (1969), Owens and King (1975) and Kenner and Ahmed (1975). Details of the procedure are described in HernándezLeón (1988b). ETS data were calculated for the "in situ" temperature using the Arrhenius equation, taking $15 \mathrm{kcal} \mathrm{mol}^{-1}$ as the activation energy (Packard et al. 1975). The other two samples were stored for taxonomical work and measurement of dry weight and ash-free dry weight.

\section{Results}

When present, the seasonal thermocline was weak during the cruise; this is characteristic for spring in these waters, where vertical mixing begins in winter and lasts until the end of May (De León and Braun 1973, Braun 1981, Hernández-León et al. 1984, Hernández-León 1988a). Higher temperatures were recorded to the west of the archipelago, in agreement with earlier studies (Mascareño and Molina 1970, Mascareño 1972, HernándezLeón and Miranda-Rodal 1987).

Low chlorophyll $a$ values $\left(0.15\right.$ to $\left.0.20 \mathrm{mg} \mathrm{m}^{-3}\right)$ were recorded throughout the archipelago; except during the late winter bloom, this is normal for the area (De Leon and Braun 1973, Braun 1981, Hernández-León et al. 1984,
Fernández de Puelles 1986). However, high mesozooplankton-biomass values were observed on the leeward side of Gran Canaria island, maximum values occurring in the central part of the island's wake; to the north, values were lower (Fig. 2). This high biomass ( $>10$ times higher than normal values for the area) is most probably related to physical factors affecting the water column around the island. We studied the wind data in relation to wake formation. For about one month prior to sampling, winds were strong, with mean daily values between 7 and $12 \mathrm{~m} \mathrm{~s}^{-1}$, and predominantly northerly (Fig. 3). Using satellite images, Van Camp and Nykjaer (1988) revealed the presence of a cold-water ring to the southwest of Gran Canaria island. This ring would seem to be an almost constant feature of the area, as it has been observed in recent satellite-monitoring studies (M. Cantón personal communication). Pérez-Martell (1988), in a comparison of wind and water current velocity around Gran Canaria, observed that the water-current speed could be roughly predicted from the wind data if wind-spced values range between 8 and $12 \mathrm{~m} \mathrm{~s}^{-1}$ and the persistence of this wind is greater than $6 \mathrm{~h}$. Using her calculations and our wind-speed values and taking the eddy viscosity of seawater to be $2.210^{-6} \mathrm{~cm}^{2} \mathrm{~s}^{-1}$ (Barkley 1972), we calculated a Reynolds number $>50$, which is higher than that given by Barkley for an eddy system downstream of a Pacific atoll (Johnston Atoll). Although we have no evidence, a cold-water ring was probably present during the cruise and has been observed recently as a dome in profiles of temperature (own unpublished data).

ETS per unit volume showed a similar pattern to that of biomass (Fig. 4A; cf. Fig. 2A). Comparisons of biomass and respiration, measured by the classic bottlemethod, have demonstrated that higher biomass results in higher oxygen consumption throughout the water column (Scholander et al. 1953, Conover 1959, Ikeda 1970, 
$16^{\circ} \mathrm{W}$

(A)

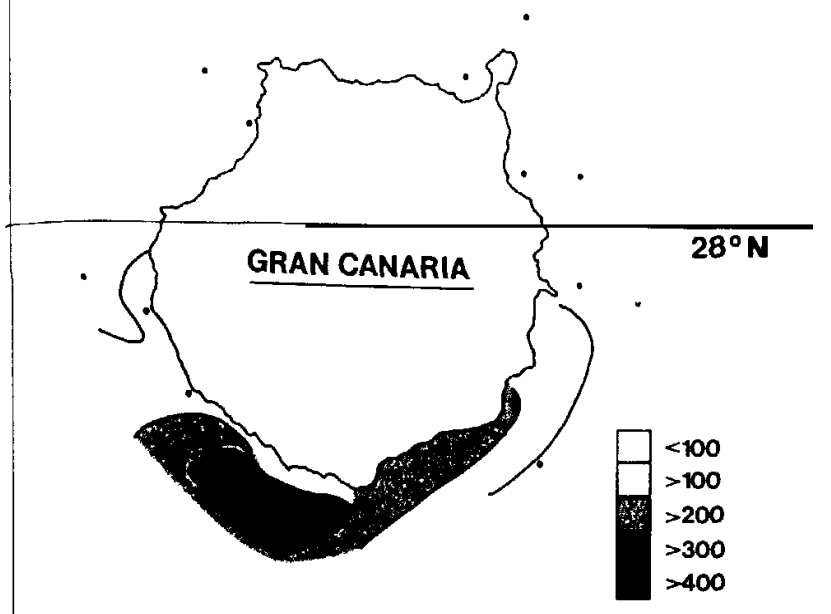

$16^{\circ} \mathrm{W}$

(B)

Fig. 2. Mesozooplankton biomass at 15 stations around Gran Canaria island, shown as displacement volume $\left(\mu 1 \mathrm{~m}^{-3} ; \mathrm{A}\right)$ and as protein content $\left(\mathrm{mg} \mathrm{m}^{-3} ; \mathbf{B}\right)$

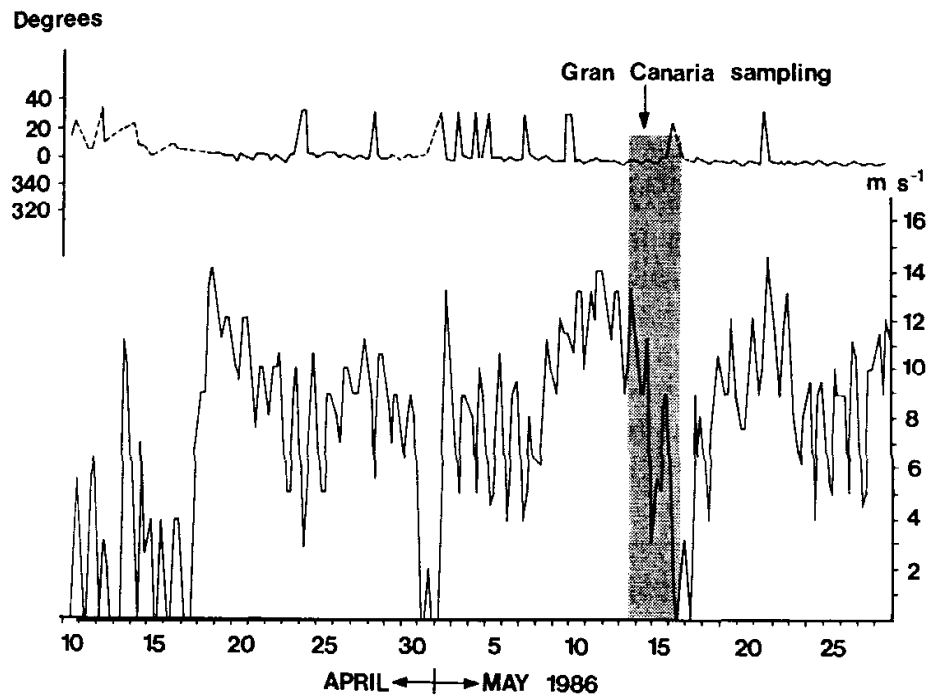

Fig. 3. Wind direction and velocity for Gran Canaria island. Data was obtained each day at $01.00,07.00,13.00$ and $18.00 \mathrm{hrs}$. Dashed portion of line indicates calm periods (no wind)
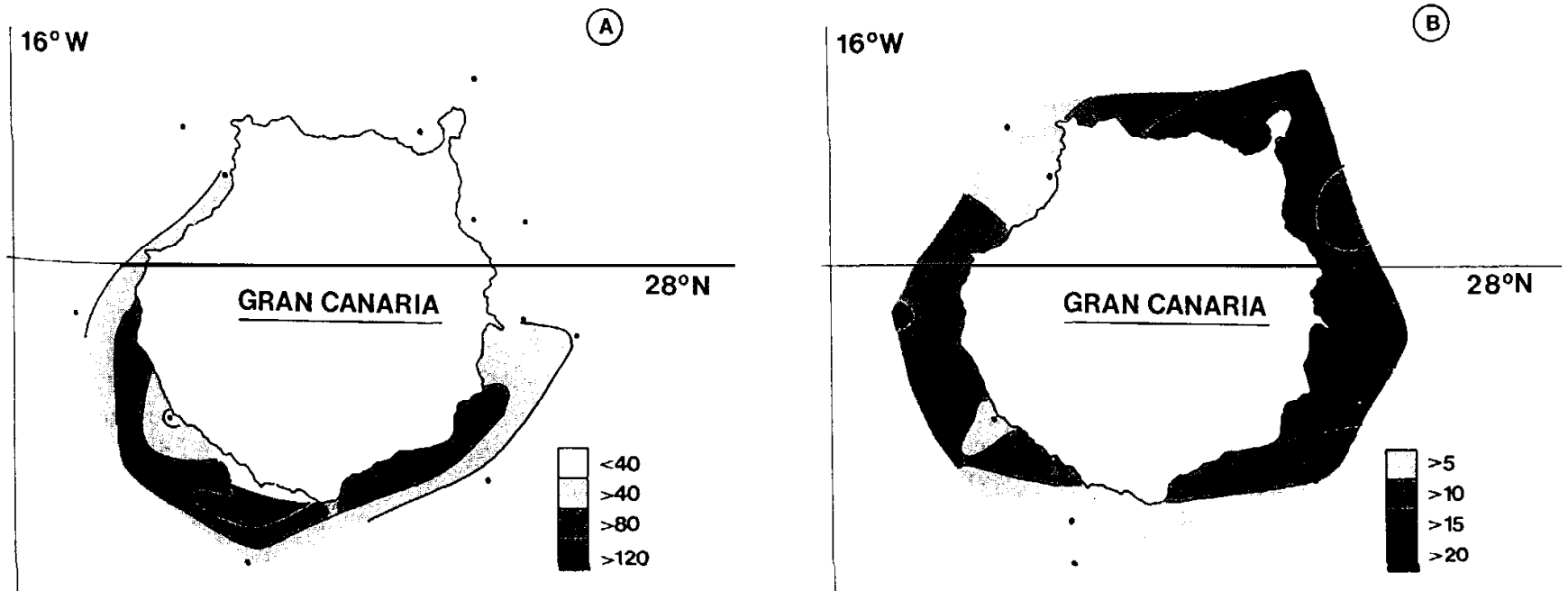

Fig. 4. Mesozooplankton electron-transport system (ETS) activity around Gran Canaria island, shown on a unit-volume basis $\left(\mu \mathrm{lO} \mathrm{m}^{-3} \mathrm{~h}^{-1} ; \mathrm{A}\right)$ and as specific activity $\left(\mu \mathrm{l} \mathrm{O}_{2} \mathrm{mg}\right.$ protein $\left.{ }^{-1} \mathrm{~h}^{-1} ; \mathrm{B}\right)$ 

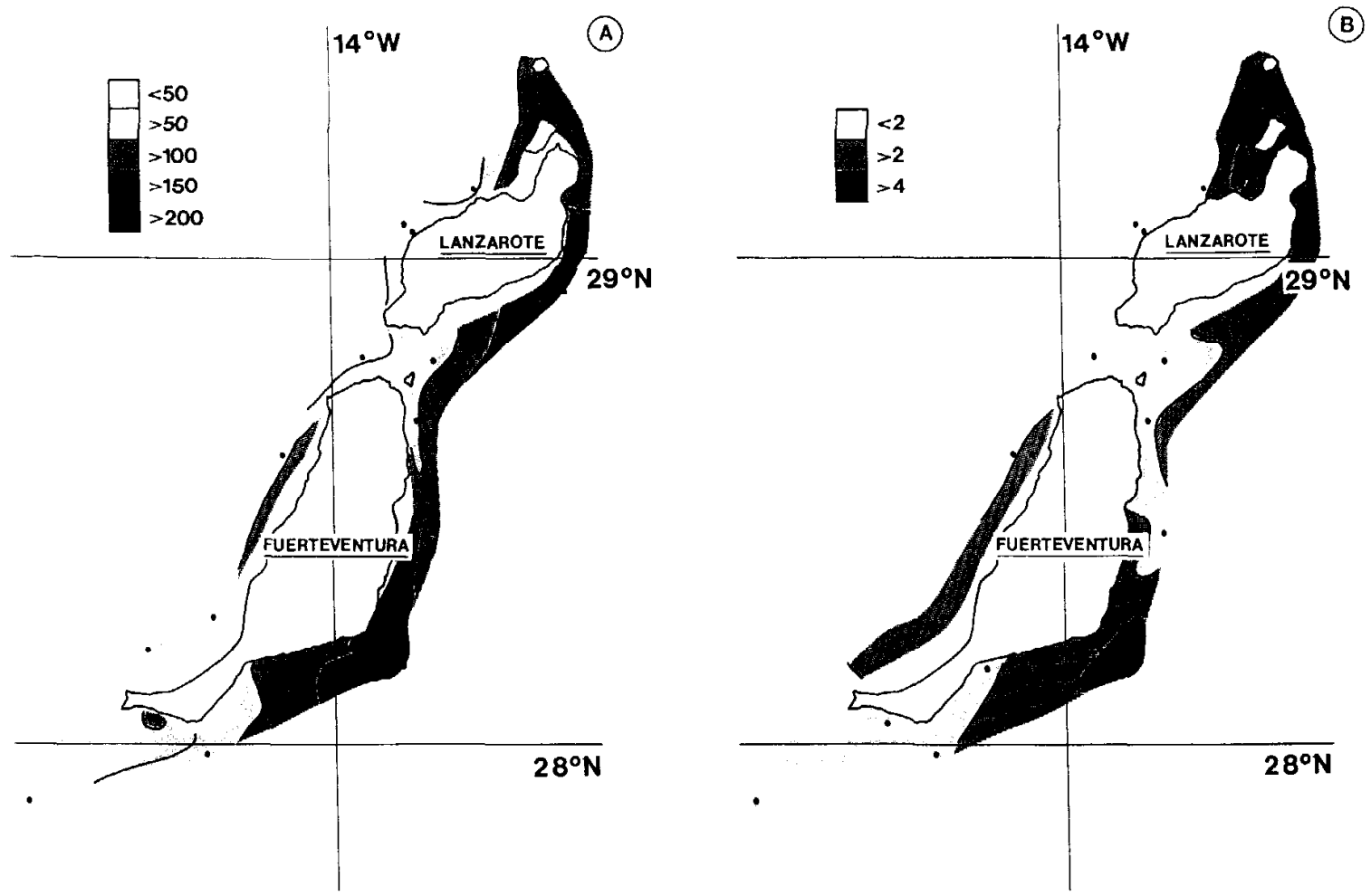

(B)

Fig. 5. Mesozooplankton biomass at 25 stations around Lanzarote and Fuerteventura islands, shown as displacement volume $\left(\mu \mathrm{l} \mathrm{m}^{-3}\right.$; $\left.\mathrm{A}\right)$ and as protein content $\left(\mathrm{mg} \mathrm{m}^{-3} ; \mathrm{B}\right)$
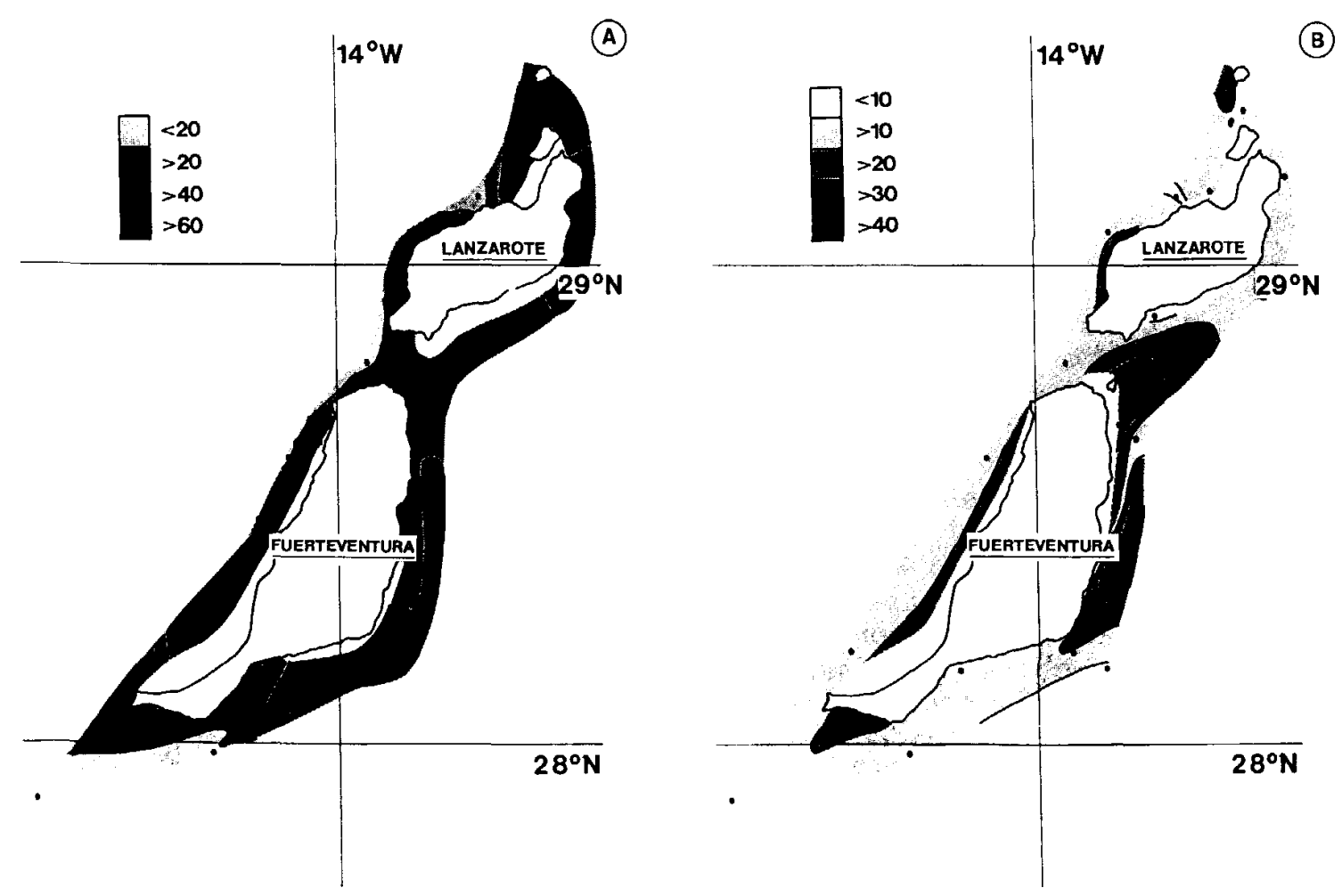

Fig. 6. Mesozooplankton ETS activity around Lanzarote and Fuerteventura islands shown on a unit-volume basis $\left(\mu \mathrm{l} \mathrm{O} \mathrm{O}^{-3} \mathrm{~h}^{-1} ; \mathrm{A}\right)$ and as specific activity $\left(\mu l \mathrm{O}_{2} \mathrm{mg}\right.$ protein $\left.{ }^{-1} \mathrm{~h}^{-1} ; \mathrm{B}\right)$ 
Table 1. Displacement volume (DV), protein content and electrontransport system (ETS) activity for the Canary Islands archipelago. Stations are grouped according to their position in relation to the northerly trade winds and the presence of the island shelf. Note that biomass is highest in Group 3, and specific ETS highest in Group 2. Values are means \pm standard deviation (SD); high SDs result from variability of conditions between the various islands

\begin{tabular}{llllll}
\hline Stations & Group & $\begin{array}{l}\mathrm{DV} \\
\left(\mu \mathrm{l} \mathrm{m} \mathrm{m}^{-3}\right)\end{array}$ & $\begin{array}{l}\text { Protein } \\
\left(\mathrm{mg} \mathrm{m}^{-3}\right)\end{array}$ & $\begin{array}{l}\text { ETS } \\
\left(\mu \mathrm{l} \mathrm{O} \mathrm{m}^{-3} \mathrm{~h}^{-1}\right)\end{array}$ & $\begin{array}{l}\text { Specific ETS } \\
\left(\mu \mathrm{l} \mathrm{O} \mathrm{mg} \mathrm{protein}^{-1} \mathrm{~h}^{-1}\right)\end{array}$ \\
\hline $\begin{array}{l}\text { Windward } \\
\text { outside shelf }(n=32)\end{array}$ & 1 & & & & \\
on shelf $\quad(n=18)$ & 2 & $83 \pm 51$ & $1.69 \pm 0.95$ & $28.76 \pm 12.66$ & $16.76 \pm 8.08$ \\
$\begin{array}{l}\text { Leeward } \\
\text { on shelf } \quad(n=13)\end{array}$ & 3 & $99 \pm 43$ & $2.60 \pm 1.57$ & $49.70 \pm 24.73$ & $18.37 \pm 3.94$ \\
$\begin{array}{l}\text { outside shelf }(n=5) \\
\text { Means }\end{array}$ & 4 & $146 \pm 113$ & $4.98 \pm 4.57$ & $67.91 \pm 36.40$ & $17.73 \pm 9.86$ \\
\hline
\end{tabular}

Nival et al. 1972). In contrast, specific ETS activity displayed a quite different pattern, consisting of two welldefined areas of relatively high activity: one to the east of Gran Canaria island and a second to the west (Fig. 4 B). ETS activity was higher in turbulent waters where the wind was strong and persistent, and lowest in the wake of the island.

Around Lanzarote and Fuerteventura, biomass (Fig. 5) and ETS per unit volume (Fig. 6A) did not display gradients as high as those observed for Gran Canaria. Mesozooplankton patches seemed to occur on shelf areas (e.g. north of Lanzarote) or in specific geographic zones of the islands such as capes, where a shearing effect of the northerly trade winds is common. Specific activity maxima occurred in the same areas as the biomass maxima. However, in the windward area to the east of Fuerteventura, a marked ETS activity gradient was apparent, which was less pronounced on the leeward side (Fig. 6B).

The biomass and ETS gradients observed around Tenerife were of lesser magnitude. As reported previously (Hernández-León and Miranda-Rodal 1987), higher biomass values were recorded on the leeward side of the island and in the wind-shear area. A secondary maximum was also encountered to the north, in a small shelf-area. Two defined gradients of ETS activity per unit volume and per unit biomass were observed, coinciding with maximum biomass values.

Around Gomera, La Palma and El Hicro Islands, maximum biomass values and ETS per unit volume were also recorded in the wake of the islands. Maximum specific ETS activity occurred at the windward stations to the north of these islands. Table 1 compares biomass and ETS activity in the different sampling areas around the islands as function of the presence of the island shelf and the position of the various sampling areas with respect to the northerly trade winds. Biomass and ETS maxima occurred at the leeward stations on the shelf. Minima were recorded at the windward stations outside the shelf edge, i.e., prior to contact of the water mass with the islands. Specific ETS activity attained a maximum at the windward stations on the shelf with the lowest standard deviation, and a minimum at the leeward stations outside the shelf edge. Mean specific activity was always higher on the shelf.

\section{Discussion and conclusions}

In May 1986, it was possible to record some of the biological processes resulting from the disturbance created by islands in typical oceanic waters when the northerly trade winds blow for a prolonged period of time. Unfortunately, no data were recorded for the cold-water ring to the southwest of Gran Canaria island which was later observed from "in situ" data and remote sensing studies. High biomass values in the wake area and the high specific ETS activity at the windward stations on the shelf are a trend general to the archipelago as a whole.

Differences in biomass were observed as a function of shape of the islands. Circular islands such as Gran Canaria displayed high values of mesozooplankton biomass, which were not recorded for oblong islands such as Lanzarote and Fuerteventura which are oriented towards the current and the northerly trade winds and do not offer significant resistance to the general water-current circulation. Surface temperature recorded by satellite images revealed the presence of well-developed wakes to the south of Gran Canaria, whereas for Lanzarote and Fuerteventura this effect was minimal (M. Cantón personal communication). In addition, the presence of an island shelf strongly influences biomass (Table 1), and is probably the cause of the lower biomass and ETS gradients observed around the western islands, whose shelves are extremely narrow. The regeneration of nutrients in the sediment on the shelf off the Canary Islands is a causative mechanism in increased productivity in these waters (Arístegui et al. 1989). The Ekman layer calculated from the wind data was about $60 \mathrm{~m}$ depth, permitting a contribution of nutrients from the benthos in shallower areas. This vertical mixing is presumably responsible for the increased biomass at depths $<60 \mathrm{~m}$ observed in an earlier study in summer, under the influence of strong northerly trade winds (Hernández-León 1988a).

Low chlorophyll $a$ values were recorded during the cruise, and no significant increase in phytoplankton biomass was observed to the leeward of the islands. These low values may be related to grazing by zooplankters, which consume about $93 \%$ of the primary production in Canary Island waters (Braun 1981). Although the latter value is probably an overestimation, it indicates that grazing has an important effect on the presence of phyto- 
plankton biomass around these islands. Unfortunately, no measurements of primary production were made. However, comparison of the values of primary production in calm areas with that in the turbulent waters of the wind-shear areas revealed a higher autotrophic production in the area of turbulence on the shelf (Aristegui et al. 1989). This correlates with the higher specific ETS activity recorded in this latter area (Table 1). Therefore, zooplankton growth will presumably be only moderate in the water column over shelf areas. Zooplankton drift and their accumulation in the wakes of islands, combined with their motility and vertical migration, could be a means of maintaining proximity to islands, where waters are potentially more productive. In addition, an anticyclonic eddy has been observed recently from "in situ" data (own unpublished data), quite near to the area where the maximum biomass off Gran Canaria was recorded (Fig. 2). Animals may be trapped in this downwelling area.

Various authors have observed increased biomass values in waters around islands (e.g. Moore 1949, Doty and Ogury 1956, Jones 1962, Hargraves et al. 1970, Simpson et al. 1972, Sander 1973, 1981, Gilmartin and Revelante 1974, Houvenaghel 1978, Moore and Sander 1979, Feldman et al. 1984, Le Borgne et al. 1985), and some have found values to be higher in the leeward side. Alldredge and Hamner (1980) observed mean biomass values up to six times higher in the leeward area of Whitsunday Island, Queensland (Australia). Le Borgne et al. (1985) found an increase in zooplankton biomass to the leeward of Mare Island, New Caledonia, which could have been caused by the accumulation processes proposed in the present study. Boden and Parker (1986) inferred that circulation around Prince Edward Island $\left(47^{\circ} \mathrm{S} ; 30^{\circ} \mathrm{E}\right)$ must prolong the residence time of macroplankton near the island. Hernández-León (1988 b) found an increase in mesozooplankton at the boundary between the calm of the wake and the turbulent surrounding waters.

The accumulation of organisms to the leeward of islands is proposed as an important causative mechanism of the island-mass effect. The mechanisms of animal concentration and the hydrodynamic features that presumably govern the drifting of plankton need to be clarified. This phenomenon may prove important to local fisheries; fish eggs and larvae remain near the island, in the wake area, as a result of the increased biomass (own unpublished data); more significant must be their higher survival rate as a consequence of the increased availability of food in these areas.

Acknowledgements. I would like to thank $\mathrm{Dr}$. J. Aristegui and $\mathrm{Dr}$. J. G. Braun for their helpful comments on the manuscript, C. Fraga Saavedra for drawing the figures, and J. P. LeGrow for linguistic corrections.

\section{Literature cited}

Alldredge, A. L., Hamner, W. M. (1980). Recurring aggregation of zooplankton by tidal current. Estuar. cstl mar. Sci. 10: 31-37 Arístegui, J., Hernández-León, S., Gómez, M., Medina, L., Ojeda, A., Torres, S. (1989). Influence of the north trade winds on the biomass and production of neritic plankton around Gran Canaria island. Scientia mar. 53: 223-229

Barkley, R. A. (1972). Johnston Atoll's wake. J. mar. Res. 30: $201-216$

Blackburn, M. (1965). Oceanography and the ecology of tunas. Oceanogr. mar. Biol. A. Rev. 3: 299-322

Boden, B. P., Parker, L. D. (1986). The plankton of the Prince Edward Islands. Polar Biol. 5: 81-93

Braun, J. G. (1980). Estudios de producción en aguas de las Islas Canarias. I. Hidrografia, nutrientes y producción primaria. Boln Inst. esp. Oceanogr. 5 (285): 149-154

Braun, J. G. (1981). Estudios de producción en aguas de las Islas Canarias. II Producción del zooplancton. Boln Inst. esp. Oceanogr. 290: 89-96

Conover, R. J. (1959). Regional and seasonal variation in the respiratory rate of marine copepods. Limnol. Oceanogr. 4: 259268

De León, A. R., Braun, J. G. (1973). Ciclo anual de la producción primaria y su relación con los nutrientes en aguas Canarias. Boln Inst. esp. Oceanogr. 167: 1-24

Doty, M. S., Oguri, M. (1956). The island mass effect. J. Cons. perm. int. Explor. Mer 22: 33-37

Feldman, G., Clark, D., Halpern, D. (1984). Satellite color observations of the phytoplankton distribution in the Eastern Equatorial Pacific during the 1982-1983 El Niño. Science, N.Y. 226: $1069-1071$

Fernández De Puelles, M. L. (1986). Ciclo anual de la comunidad de meso y microzooplancton; su biomasa, estructura, relaciones tróficas y producción en aguas de las Islas Canarias. Tesis. Universidad de Madrid

Gilmartin, M., Revelante, N. (1974). The "island mass" effect on the phytoplankton and primary production of the Hawaiian Islands. J. exp. mar. Biol. Ecol. 16: 181-204

Hargraves, P. E., Brody, R. W., Burkholder, P. R. (1970). A study of phytoplankton in the Lesser Antilles region. Bull. mar. Sci. 20: $331-349$

Hernández-León, S. (1986). "Efecto de masa de isla" en aguas del Archipiélago Canario según estudios de biomasa y actividad del sistema de transporte de electrones en el mesozooplancton. Tesis. Universidad La Laguna

Hernández-León, S. (1987). Actividad del sistema de transporte de electrones en el mesozooplancton durante un máximo primaveral en aguas del Archipiélago Canario. Investigación pesq. 51: 491-499

Hernández-León, S. (1988 a). Ciclo anual de la biomasa del mesozooplancton sobre un área de plataforma en aguas del Archipiélago Canario. Investigación pesq. 52: 3-16

Hernández-León, S. (1988 b). Gradients of mesozooplankton biomass and ETS activity in the wind shear area as evidence of an island mass effect in the Canary Island waters. J. Plankton Res 10: $1141-1154$

Hernández-León, S., Llinás, O., Braun, J. G (1984). Nota sobre la variación de la biomasa del mesozooplancton en aguas de Canarias. Investigación pesq. 48: 495-508

Hernández-León, S., Miranda-Rodal, D. (1987). Actividad del sistema de transporte de electrones y biomasa del mesozooplancton en aguas de las Islas Canarias. Boln Inst. esp. Oceanogr. 4 (2): $49-62$

Houvenaghel, G. T. (1978). Oceanographic conditions in the Galapagos Archipelago and their relationships with life on the islands. In: Boje, R., Tomczak, M. (eds.) Upwelling ecosystems. Springer-Verlag, Berlin, Heidelberg, New York, p. 181-200

Ikeda, T. (1970). Relationship between respiration rate and body size in marine plankton animals as a function of the temperature of habitat. Bull. Fac. Fish. Hokkaido Univ. 21: 91-112

Jones, E. C. (1962). Evidence of an island effect upon the standing crop of zooplankton near the Marquesas Islands, Central Pacific. J. Cons. perm. int. Explor. Mer 27: 223-231

Kenner, R. A., Ahmed, S. I. (1975). Measurements of electron transport activities in marine phytoplankton. Mar. Biol. 33: $119-127$ 
Le Borgne, R. P., Dandonneau, Y., Lemasson, L. (1985). The problem of the island mass effect on chlorophyll and zooplankton standing crops around Mare (Loyalty Islands) and New Caledonia. Bull. mar. Sci. 37: 450-459

Lowry, P. H., Rosenbrough, N. J., Farr, A. L., Randall, R. J. (1951). Protein measurement with a Folin phenol reagent. J. biol. Chem. 193: $265-275$

Mascareño, D. (1972). Algunas consideraciones oceanográficas de las aguas del Archipiélago Canario. Boln Inst. esp. Oceanogr. 158: $1-79$

Mascareño, D., Molina, R. (1970). Contribution à l'étude de l'upwelling dans la zone Canarienne africaine. Rapp. P.-v. Réun. Commn. int. Explor. scient. Mer Méditerr. 159: 61-73 atzen, F. L. (1986). Corrientes en la región comprenlas Islas Canarias orientales, Maruecos y las Islas ampaña Norcanarias I. Revta Geofis. 42: 41-52

Mc 1949). The zooplankton of the upper waters of the Coll. 12: 1-97

Moore, E., Sander, F. (1979). A comparative study of zooplankton from oceanic, shelf and harbour waters of Jamaica. Biotropica 11: $196-206$

Nival, P., Nival, S., Palazzoli, I (1972). Données sur la respiration de différents organismes communs dans le plancton de Villefranche-sur-Mer. Mar. Biol. 17: 63-76

Owens, T. G., King, F. D. (1975). The measurement of respiratory electron-transport-system activity in marine zooplankton. Mar. Biol. 30: 27-36

Packard, T. T. (1969). The estimation of the oxygen utilization rate in seawater from the activity of the respiratory electron transport system in plankton. Ph. D. thesis. University of Washington, Seattle

Packard, T. T., Devol, A. H., King, F. D. (1975). The effect of temperature on the respiratory electron transport system in marine plankton. Deep-Sea Res. 22: 237-249

Pérez-Martell, E. (1988). Interacción vientos-corrientes en profundidades reducidas. Un modelo para la costa este de Gran Canaria. Tesis, Universidad Politécnica de Canarias

Sander, F. (1973). Internal waves as causative mechanisms of island mass effects. Caribb. J. Sci. 13: 179-182

Sander, F. (1981). A preliminary assessment of the main causative mechanisms of the "island mass" effect of Barbados. Mar. Biol. 64: 199-205

Scholander, P. F., Flagg, W., Walters, V., Irving, L. (1953). Climatic adaptation in arctic and tropical poikilotherms. Physiol. Zoöl. 26: $67-92$

Simpson, J. H., Tett, P. B., Argote-Espinoza, M. L., Edwards, A., Jones, K. J., Savidge, G. (1982). Mixing and phytoplankton growth around an island in a stratified area. Contin. Shelf Res. 1: $15-31$

Sund, P. N., Blackburn, M., Williams, F. (1981). Tunas and their environment in the Pacific Ocean: a review. Oceanogr. mar. Biol. A. Rev. 19: 443-512

UNESCO (1968). Zooplankton sampling. Monogr. oceanogr. Methodol. (UNESCO) 2: 1-174

Van Camp, L., Nykjaer, L. (1988). Remote sensing of the Northwest African upwelling area. Commission of the European Communities. Joint Research Centre, Ispra, Italy (Internal tech. Rep.) 